\title{
Everyday Representations of Tax Avoidance, Tax Evasion, and Tax Flight: Do Legal Differences Matter? ${ }^{\S}$
}

\author{
Erich Kirchler ${ }^{*}$, Boris Maciejovsky ${ }^{\circ}$, Friedrich Schneider ${ }^{\ddagger}$ \\ June, 2001
}

\begin{abstract}
From an economic point of view, legal considerations apart, tax avoidance, tax evasion and tax flight have similar effects, namely a reduction of revenue yields, and are based on the same desire to reduce the tax burden. Due to legal differences and moral concerns it is, however, likely that individuals perceive them as different and as unequally fair.

Overall, 252 fiscal officers, business students, business lawyers, and entrepreneurs produced spontaneous associations to a scenario either describing tax avoidance, tax evasion, or tax flight, and evaluated them as positive, neutral or negative.

The results indicate that everyday representations differ with respect to tax avoidance, tax evasion, and tax flight. Tax evasion was perceived rather negatively, tax flight neutrally, and tax avoidance positively. Although fiscal officers judged all forms of tax reduction least fair, all sub-samples found tax evasion less fair than tax avoidance or tax flight. With regard to knowledge of tax law and fairness perception, differential effects were found: Business lawyers and entrepreneurs judged tax avoidance the fairer the higher their knowledge was. Fiscal officers, on the other hand, found tax evasion especially unfair if their knowledge was high.
\end{abstract}

Keywords: Tax Evasion; Everyday Representations; Tax Knowledge

JEL-Classification: H26; K34; K42

PsycInfo Classification: 2900; 4200

\footnotetext{
$\S$ The authors gratefully acknowledge research assistance by Michael Senoner and Nicola Trink. Valuable comments by Werner Güth are also gratefully acknowledged.

${ }^{*}$ University of Vienna, Department of Psychology, Unit of Economic Psychology, Universitaetsstrasse 7, A1010 Vienna, Austria. Tel. +43/1/4277-47880, Fax: +43/1/4277-47889, e-mail: erich.kirchler@univie.ac.at 'Humboldt-University of Berlin, Department of Economics, Institute for Economic Theory III, Spandauer Strasse 1, D-10178 Berlin, Germany. Tel. +49/30/2093-5790, Fax: +49/30/2093-5704, e-mail: maciej@wiwi.huberlin.de

¥ Johannes Kepler University of Linz, Department of Economics, A-4040 Linz-Aufhof, Austria. Tel. +43/732/2468-8210, Fax: +43/732/2468-8209, e-mail: friedrich.schneider@jk.uni-linz.ac.at Financial support was received by the Deutsche Forschungsgemeinschaft, SFB 373 ("Quantifikation und Simulation Ökonomischer Prozesse"), Humboldt-Universität zu Berlin.
} 


\section{Introduction}

From a macro-economic perspective - legal considerations apart - tax avoidance, tax evasion, and tax flight have similar negative effects on the national budget. Hence, economists suggest to analyze their effects jointly, and no longer discriminate between them (e.g., Cross and Shaw, 1982). However, from a psychological perspective, due to legal differences and moral considerations (Etzioni, 1988), it is assumed that taxpayers perceive tax avoidance, tax evasion, and tax flight differently, despite their identical economic consequences.

In this paper we contrast the two research positions by investigating social representations of tax avoidance, tax evasion, and tax flight. Social representations (Moscovici, 1981; 1984) allow a direct comparison of economic and psychological predictions on the same data level. Since the economic line of reasoning focuses on the macro-perspective, we cannot study individual opinions or attitudes but rather their socially embedded equivalents, the so-called social representations.

The paper is organized as follows: In section 1.1 definitions of tax avoidance, tax evasion, and tax flight are provided as well as empirical research is discussed. Section 1.2 deals with the concept of social representations, and in section 1.3 our hypotheses are introduced. Section 2 deals with the research method, particularly with the participants, design, material, and procedure. In section 3 our results are presented and discussed, particularly focussing on the central core of social representations, their semantic contents, attitudes towards tax avoidance, tax evasion, and tax flight, their perceived fairness, tax knowledge, as well as individual tax compliance within the context of employment group. A conclusion is presented in section 4 .

\subsection{Tax avoidance, tax evasion, and tax flight}

Tax avoidance refers to an attempt to reduce tax payments by legal means, for instance by exploiting tax-loopholes, whereas tax evasion refers to an illegal reduction of tax payments, for instance by underreporting income or by stating higher deduction-rates. ${ }^{1}$ Tax flight refers to the relocation of businesses, only in order to save taxes, for instance by making use of offshore tax havens.

Since tax avoidance, tax evasion, and tax flight have similar effects, economists suggest not to differentiate between them but to analyze their effects jointly (Cross and Shaw, 1982). However, this line of argumentation - solely focussing on analytical research methods - takes not into account results of empirical evidence on actual tax behavior. The prescriptive power of analytical models of tax evasion (e.g., Allingham and Sandmo, 1972), mainly focussing on exogenous variables like audit-frequency and sanction, lack conclusive empirical evidence (Alm, McClelland and Schulze, 1999; Baldry, 1987; Bosco and Mittone, 1997; Cullis and Lewis, 1997; Kaplan and Reckers, 1985; Webley, Robben, Elffers and Hessing, 1991). Thus, monetary consequences alone seem not sufficient to reliably predict and describe actual tax behavior. However, in formal economic models individuals are considered to solely passively react to exogenous variables, and to pay taxes only because they fear audits and sanctions. Intrinsic motives, such as perceived fairness, cooperation or social norms, remain unconsidered.

In most countries, however, audit-frequencies are remarkable low and sanctions mostly imply just the payment of unpaid taxes and only a minor fine, indicating that a purely economic

\footnotetext{
${ }^{1}$ In reality however there are many gray areas that do not permit an easy differentiation between tax avoidance and tax evasion (Slemrod and Yitzhaki, 2000).
} 
analysis of tax evasion is insufficient. If individuals consider tax payments as a gamble, solely specified by exogenous variables, the best choice would be to evade (Alm, McClelland and Schulze, 1992). Yet, in reality compliance rates were found to be higher than predicted from a purely economic viewpoint. Thus, it can be assumed that in addition to exogenous variables also intrinsic variables, such as perceived fairness, cooperation or social norms, are of fundamental importance in tax decisions.

A substantial body of literature confirms the importance of psychological factors on the decision-outcome with respect to tax evasion, like framing effects (e.g., Chang, Nichols and Schultz, 1987; Kirchler and Maciejovsky, 2001; Robben, Webley Elffers and Hessing, 1990; Schepanski and Shearer, 1995), perceived justice and fairness (e.g., Dornstein, 1987; Kirchler, 1997; Spicer and Becker, 1980; Spicer and Lundstedt, 1976), the importance of attitudinal aspects (e.g., Kirchler, 1999; Lewis, 1979; Vogel, 1974), the role of opportunity (e.g., Clotfelter, 1983; Groenland and van Veldhoven, 1983; Porcano, 1988; Wärneryd and Walerud, 1982; Wallschutzky, 1984; Weigel, Hessing and Elffers, 1987), etc. There are also other studies focussing on legal tax avoidance, indicating that respondents believe that the "ordinary people" have to bear most of the tax burden (Kinsey, 1984) and that they wish to reduce tax-loopholes (Song and Yarbrough, 1978). However, while there is a large number of studies available either focussing on tax avoidance or on tax evasion, hardly any studies have been concerned with the differentiation of tax avoidance and tax evasion.

\subsection{Social representations}

Everyday representations are the central topic of social representations theory. Social representations are defined as socially shared ideas, opinions, and attitudes (Moscovici, 1981; 1984). They are a broadly defined concept, capturing social reality, and having similarity with myths, beliefs, and ideologies. Moscovici and Hewstone (1983) extend the concept of social representations by defining them as "common-sense" theories. Thus, instead of focussing on individual attitudes and opinions, everyday-knowledge becomes the center of research interest.

Socially shared knowledge, concepts, and beliefs which are generated in a social net comprise psychological as well as sociological factors. The production and the function of social representations are closely related to one another. Social representations serve as means to establish coherence within groups and to allow a distinction between groups.

Social representations are frequently not investigated by questionnaires, structured interviews or experiments, but rather by methods allowing respondents to reply freely, for instance by producing spontaneous associations to a stimulus object.

Especially French psychologists developed theory and method. When free associations are produced to one or more stimulus objects, often frequencies of associations to stimuli are analyzed by correspondence analyses which produce a cognitive and evaluative map or space of associations and stimuli and to allow to detect typical characteristics of the stimuli and differentiations between them. Vergès (1987) distinguishes between three aspects of social representations: (i) relevant attitudes, opinions and evaluations towards an object, (ii) available information and knowledge about an object, and (iii) the structure of emotional, cognitive, and motivational factors associated with an object. Abric (1996) distinguishes between the central core and the peripheral system of social representations. The central core is defined as a stable, un-negotiable, and non-transformable part of the representations, whereas the peripheral system accounts for inter-individual differences with respect to a 
stimulus object. Vergés and Bastounis (2001) describe the analysis of the central core and periphery of a representation by the method of evocation. This method requires participants to spontaneously produce associations to a stimulus. The examination of data starts by a lexicographical term analysis in which neither associations nor synonyms are categorized in one group of associations. First frequencies of associations are counted and the mean rank in the production series is calculated. Second, frequently and at the beginning of the association task mentioned terms are grouped, indicating the elements of the nucleus of a representation. Terms mentioned either less frequently but at the beginning of the association task and terms mentioned with high frequency but toward the end indicate the first periphery, and those terms mentioned with low frequency and late in the task indicate the second periphery.

\subsection{Hypotheses}

Empirical evidence indicates that formal economic models of tax behavior lack conclusive empirical evidence. The deterrent effects of economic determinants, such as audit-frequency and sanction, were found not to be sufficient in order to fully describe and explain individual tax behavior. Moreover, in addition to economic determinants of tax decisions also psychological factors, such as perceived fairness, cooperation or social norms, were found to be important in describing and understanding tax behavior.

Thus, despite the fact that from an economic viewpoint, legal considerations apart, tax avoidance, tax evasion, and tax flight have similar effects on the national budget and are based on the same desire to reduce the tax burden, we hypothesize from a psychological viewpoint that taxpayers discriminate between them, and evaluate tax avoidance, tax evasion, and tax flight differently. According to the macro-perspective of the economic line of reasoning, social representations are investigated in order to contrast predictions of economics and psychology on the same data level.

Hypothesis 1: An analysis of social representations of tax avoidance, tax evasion, and tax flight allows for a clear distinction between the concepts, indicating that tax avoidance, tax evasion, and tax flight are perceived socially differently, despite their identical reductions of revenue yields.

Moreover, we do not only expect that tax avoidance, tax evasion, and tax flight are clearly discriminated from one another, but that they are also perceived as unequally fair by the taxpayers. Since tax avoidance is a legal means to reduce one's tax burden, whereas tax evasion involves a criminal and illegal offence, we hypothesize that the former is perceived as fairer than the latter. Tax flight, however, defined as the relocation of businesses, only in order to save taxes, is less unambiguous. While tax flight is clearly no criminal offence, it still seems immoral, since individuals involved in tax flight only intend to reduce their tax burden. Thus, we hypothesize that tax flight is perceived as less fair than legal tax avoidance, but at the same time as fairer than illegal tax evasion.

Hypothesis 2: Tax avoidance is expected to be evaluated fairer than tax flight which in turn is expected to be evaluated fairer than tax evasion.

Empirical evidence indicates that tax knowledge is correlated with tax compliance. Groenland and van Veldhoven (1983) report that profound tax knowledge implies low tax compliance, whereas the results of a study by Kirchler and Maciejovsky (2001) imply the opposite to be true, little tax knowledge was associated with low tax compliance. Eriksen and Fallan (1996) show that following an increase in tax knowledge, respondents consider their own tax evasion 
as more serious, the perceived fairness in taxation increased, and attitudes towards other people's tax evasion became stricter.

Since Kirchler and Maciejovsky (2001) report that little tax knowledge is associated with low tax compliance, one plausible explanation could be that tax knowledge is positively correlated with attitudes towards legal tax avoidance and at the same time negatively correlated with attitudes towards illegal tax evasion. Thus, profound tax knowledge is assumed to lead one to perceive tax avoidance more positively than tax evasion, whereas little tax knowledge is assumed to imply the opposite, namely to perceive tax evasion more positively than tax avoidance.

Hypothesis 3: Tax knowledge is positively correlated with attitudes towards legal tax avoidance and negatively correlated with attitudes towards illegal tax evasion.

Empirical evidence also shows that the opportunity to evade taxes influences individual tax compliance (e.g., Porcano, 1988; Wärneryd and Walerud, 1982; Wallschutzky, 1984; Weigel, Hessing and Elffers, 1987). Since in most industrialized countries, taxes for the employed are usually withheld from their salaries and wages, whereas self-employed and entrepreneurs pay taxes out of their pocket, based on their own information provided, we hypothesize that the latter show less compliance than the former. Clotfelter (1983) analyzed a sample of 47,000 individual tax returns for the year 1969 and found that underreporting varies with respect to employment group, and Groenland and van Veldhoven (1983) report that experience with black money varies between employed and unemployed. Thus, with respect to opportunity we hypothesize that individual tax compliance in our study is lower for the group of business entrepreneurs than for the employed groups of business lawyers and fiscal officers. Since business students do not have a regular income from work, they are not considered in our analysis.

Hypothesis 4: Individual tax compliance is lower for business entrepreneurs than for business lawyers and fiscal officers.

\section{Method}

\subsection{Participants and design}

Overall, 252 fiscal officers, students of economics and business administration specializing in auditing and accounting, business lawyers, and entrepreneurs participated in the study. A detailed description of the sub-samples is provided in Table 1.

The study was conducted as a 3 x 4 factorial design. Independent variables were (i) a fictive scenario of a person engaged in tax avoidance, tax evasion, or tax flight, and (ii) respondents' employment groups (tax officers, business students, business lawyers, and entrepreneurs). It should be emphasized that the terms tax avoidance, tax evasion, and tax flight were never used in the scenarios explicitly. Both experimental factors were between-subjects factors, and participants were randomly presented one of the three scenarios. The assignment of employment groups to scenario conditions is shown in Table 2.

\subsection{Material and procedure}

Participants read one of the three scenarios (see Figure 1), produced spontaneous associations to it, and evaluated them as positive, neutral or negative. Before starting the associative task, participants were asked to answer a control question about the scenario for a manipulation 
check. Overall, ten participants failed to respond correctly. Their data were excluded from the analyses. In addition to the associations, participants were asked to judge perceived fairness of tax avoidance, tax evasion, and tax flight (scale ranging from $1=$ unfair to $9=$ fair), and to respond to a multiple-choice test on tax knowledge (see Appendix B). Those participants confronted with the scenario describing a person engaged in tax evasion were also asked to state how much they think the person described in the scenario would honestly declare to the tax authorities.

Table 1: Socio-demographic characteristics of the sample

\begin{tabular}{lccccc}
\hline \hline Characteristics & Fiscal officers & $\begin{array}{c}\text { Business } \\
\text { students }\end{array}$ & $\begin{array}{c}\text { Business } \\
\text { lawyers }\end{array}$ & Entrepreneurs & Total \\
\hline $\mathrm{N}$ & 75 & 82 & 56 & 39 & 252 \\
Sex & 34 & 40 & 17 & 8 & 99 \\
$\quad$ Female & 32 & 40 & 39 & 29 & 140 \\
Male & 9 & 2 & 0 & 2 & 13 \\
Missing values & & & & & \\
Age & 28.84 & 26.13 & 33.43 & 45.74 & 31.62 \\
M & 7.06 & 6.86 & 6.17 & 12.50 & 10.28 \\
SD & 19 & 2 & 0 & 4 & 25 \\
Missing values & & & & & \\
Formal education & 0 & 0 & 0 & 16 & 16 \\
Compulsory school & 45 & 74 & 0 & 12 & 131 \\
Secondary school & 23 & 6 & 56 & 8 & 12 \\
College/university & 7 & 2 & 0 & 3 & \\
Missing values & & & & & \\
Net monthly income in & & & & & \\
Austrian Shillings & 0 & 55 & 0 & 4 & 73 \\
$<10,000$ & 51 & 9 & 4 & 9 & 35 \\
10,001 - 20,000 & 11 & 5 & 13 & 6 & 29 \\
20,001 - 30,000 & 1 & 2 & 11 & 15 & 30 \\
30,001 - 40,000 & 0 & 0 & 26 & 0 & 5 \\
$>40,000$ & 12 & 11 & 2 & 5 \\
Missing values & & & & & \\
\hline
\end{tabular}

Note: 100 Austrian Shillings equal 7.27 Euro or 6.92 US\$ (June, 2000)

Table 2: Participants by experimental condition

\begin{tabular}{lccccc}
\hline Employment groups & Tax avoidance & $\begin{array}{c}\text { Scenario } \\
\text { Tax } \\
\text { evasion }\end{array}$ & $\begin{array}{c}\text { Tax } \\
\text { flight }\end{array}$ & $\begin{array}{c}\text { Incorrectly answered } \\
\text { control question }\end{array}$ & Total \\
\hline Fiscal officers & 21 & 21 & 33 & 3 & 75 \\
Business students & 27 & 28 & 27 & 5 & 82 \\
Business lawyers & 19 & 16 & 21 & 0 & 56 \\
Entrepreneurs & 13 & 15 & 11 & 2 & 39 \\
Total & 80 & 80 & 92 & 10 & 252 \\
\hline
\end{tabular}

Fiscal officers were approached during a further education program; students at lectures at the university; business lawyers were contacted through large law agencies; and entrepreneurs were contacted in their firms and stores. Responding to the questionnaire took approximately 25 minutes. 
Figure 1: Scenario about tax avoidance, tax evasion, and tax flight

Please, put yourself in the situation described below:

Mr. Paul K. is owner of a successful travel agency.

Last month he has earned an extra income in the amount of 75,000 Austrian Shillings for organizing a special event.

Mr. Paul K. considers to make use of legal tax loopholes in order to reduce his tax payments.

(Mr. Paul K. considers not to declare his extra income in his income declaration.)

[Mr. Paul K. considers to relocate his headquarters to another country in order to reduce the tax burden in the future.]

Note: The expression in the third paragraph without parentheses describes tax avoidance, the expression in parentheses describes tax evasion, whereas the expression in brackets describes tax flight.

\section{Results and Discussion}

In the following, free associations of four employment groups on tax avoidance, tax evasion, and tax flight were analyzed, (i) for detection of a possible central core and the peripheral system of social representations, and (ii) for semantic contents. Moreover, (iii) attitudes towards tax behavior and (iv) fairness judgments were investigated, (v) tax knowledge, as well as (vi) individual tax compliance within the context of employment group.

\subsection{Central core of social representations towards tax behavior}

Participants were asked to produce spontaneous associations to the scenario in the questionnaire. Overall, 880 associations were produced, 507 of them were different. In the condition with the scenario on tax avoidance, 261 associations were counted of which 156 were different. In the condition on tax evasion, 309 associations were generated of which 182 were different, and in the condition on tax flight, participants produced 310 different associations of which 169 were different.

Table 3: Most likely core elements of the associations on tax avoidance, tax evasion, and tax flight

\begin{tabular}{|c|c|c|c|c|c|c|c|c|}
\hline \multicolumn{3}{|c|}{ Tax avoidance } & \multicolumn{3}{|c|}{ Tax evasion } & \multicolumn{3}{|l|}{ Tax flight } \\
\hline Associations & $\mathrm{f}$ & $\mathrm{M}$ & Associations & $\mathrm{f}$ & $\mathrm{M}$ & Associations & $\mathrm{f}$ & $\mathrm{M}$ \\
\hline Legal & 15 & 2.33 & Illegal & 12 & 2.08 & Tax saving & 10 & 1.40 \\
\hline Tax saving & 8 & 1.63 & Fraud & 7 & 1.86 & Lower taxes abroad & 9 & 3.40 \\
\hline Clever & 8 & 3.00 & Income declaration & 7 & 3.29 & Double tax agreement & 5 & 3.20 \\
\hline Good idea & 5 & 1.60 & Criminal prosecution & 6 & 2.00 & & & \\
\hline Costs & 5 & 2.60 & Risk & 5 & 2.80 & & & \\
\hline & & & Tax-audit & 5 & 3.60 & & & \\
\hline & & & Black money & 5 & 5.00 & & & \\
\hline
\end{tabular}

Note: The columns f refer to the absolute frequency of associations, and the columns $\mathrm{M}$ display the mean of the positions of the associations.

Table 3 displays the frequencies of associations and the mean rank in the series of production (terms mentioned by less than five participants are not included). Only those associations were analyzed which were not literal repetitions of what was written in the scenarios. The 
most likely core elements of the associations on tax avoidance, tax evasion, and tax flight are those mentioned frequently and at the beginning of the associative task. Since no significant differences between the sub-samples were found, the total sample was analyzed.

Tax avoidance was associated with legal, with an intention to save taxes, with cleverness and a good idea as well as with costs. Tax evasion, on the other hand, was associated with illegal, fraud, criminal prosecution, risk, tax-audit, punishable, penalty, and the risk of getting caught. Also, rather neutral associations like income declaration and tax saving as well as black money were produced. Tax flight was associated with an intention to save taxes, with an impression that taxes are substantially lower abroad as well as with double tax agreement and costs of relocation.

Participants clearly distinguished between tax avoidance, tax evasion, and tax flight in their spontaneously produced associations as expected under hypothesis 1 . The most likely core elements of tax avoidance refer to legality and cleverness, whereas tax evasion was considered to be illegal, a criminal offence, and as being risky. Eventually, tax flight was associated with the lower perceived tax burden abroad and with an intention to save taxes, but also with associated costs of relocating and with the restriction of double tax agreements. Interestingly, tax saving was considered to be a motive for all three tax-reduction possibilities, namely for tax avoidance, tax evasion, and for tax flight. However, they differ with respect to the perceived importance of that motive. Tax saving was highly considered to be a central motive for tax flight and tax avoidance, but was only mentioned relatively late in the association process for tax evasion, indicating that the wish to save taxes is overlaid by thoughts of illegality, risk, or by criminal prosecution.

\subsection{Semantic content of social representations towards tax behavior}

In a further step of analysis, the 507 different associations were regrouped in categories of synonyms. First, four experts developed a category scheme according to the associations. Overall, 35 semantic categories plus an additional category for those associations that do not fit in the regular scheme were developed. Then, three further experts were explained the categories and instructed to categorize independently all different associations into the 36 categories. In case of disagreement the experts had to further discuss until an agreement was reached. Table 4 (in the Appendix A) shows the categories and the respective characteristic associations as well as frequencies of associations by experimental conditions. The categories "literal repetition of the scenario" as well as the "rest"-category were not included in the analysis. $^{2}$

A correspondence analysis on frequencies displayed in Table 4 yielded two dimensions which explained $31 \%$ and $23 \%$ of the variance. The two dimensions divide the data according to (i) legality and (ii) to morality. Figure 2 (also in the Appendix A) indicates that the produced associations on tax avoidance, tax evasion, and tax flight are clearly differentiated from one another as indicated by the corresponding clusters, irrespective of the employment group.

Tax avoidance was perceived as legal and as moral, tax evasion as illegal and immoral, and finally tax flight as legal and as immoral. More precisely, tax avoidance was associated with the acceptance of tax reduction, the make use of tax allowances, legal tax reduction, horizontal justice, and with tax loophole. Tax evasion was associated with risk tendency, peccadillo, intentional evasion, audit and sanction, opportunity, black money, unacceptance,

\footnotetext{
${ }^{2}$ An additional correspondence analysis was run with all 36 categories leading to similar results.
} 
unintentional errors, and with vertical justice. Hence, tax evasion again is basically associated with shadow economy and is considered as a criminal offence. ${ }^{3}$ Tax flight was associated with tax havens, negative consequences of tax flight, with flight abroad, bureaucracy, economic advantages of tax flight, economic consequences, with unprofitable, with criticism on the tax system, and with the wish to reduce the tax burden. It might be interesting to note that sanctions and audits - determinants of evasion considered in economic models - were associated with tax evasion. However, also vertical justice and opportunity to evade were typical associations. Opportunity and justice considerations are frequently studied variables in psychological investigations (e.g., Dornstein, 1987; Kirchler, 1997; Spicer and Becker, 1980; Spicer and Lundstedt, 1976). While vertical justice proved to be relevant with tax evasion, horizontal justice was associated with tax avoidance. Also reactance and injustice in general were related to tax avoidance. Tax flight, on the other hand, seems to be considered if bureaucray is increasing.

\subsection{Attitudes towards tax behavior}

Participants were asked to evaluate their spontaneously produced associations. According to these responses attitudinal indices were computed (de Rosa, 1996). The polarity index results from the difference between the number of positive and negative associations, related to the total number of associations produced by a participant. It ranges from - 1 (negative attitude) to +1 (positive attitude). The neutrality index is calculated as the relative frequency of neutral associations related to the total number of associations. It varies from 0 to 1 .

Two 3 by 4 analyses of variance with scenario and employment groups as independent variables and polarity index as well as neutrality index as dependent variables yielded the following results: For the polarity index, only the scenario was significant $(\mathrm{F}(2 ; 208)=5.22 ; \mathrm{p}$ $<.001)$, indicating that independent of employment group $(\mathrm{F}(3 ; 208)=0.95, \mathrm{p}=.42)$, participants produced most negative associations in the condition of tax evasion $(\mathrm{M}=-.26$; $\mathrm{SD}=.48)$; rather neutral associations in the tax flight condition $(\mathrm{M}=.11 ; \mathrm{SD}=.56)$ and relatively positive associations in the tax avoidance condition $(\mathrm{M}=.29$; $\mathrm{SD}=.52)$, as

\footnotetext{
${ }^{3}$ In a study about "Individual behaviour in the shadow economy in Australia" Schneider, Braithwaite and Reinhart (2001) investigated how individuals act with respect to be engaged in shadow economy activities which is always linked with tax evasion. In this study a detailed investigation is made, what are the reasons, why people work in the shadow economy, how they react to a rising tax burden and how they evaluate the risks of being "caught" by the tax authorities. As this is all closely linked with the results of this paper some of the results are briefly reported here. Not astonishing is that those who are engaged in shadow economy activities to a much larger degree, argue that income taxes are too high and that they should less honestly declare all cash earnings (significant result in a logistic regression with a dependent variable, people working in the shadow economy $=0$, people not working in the shadow economy $=1$ ). Also those who work in the shadow economy think that the changes are small, that they will be caught by the tax authorities, compared to those, who do not work in the shadow economy. Moreover those who work in the shadow economy think it is smart to do so, because they can get additional income and are unsatisfied with the amount of goods and services, the state authorities provide them. To provide a few more detailed results, $33 \%$ of those who work in the shadow economy (either demand or supply it), think, that the chances that you will get caught by the tax authorities are about 0 , compared to $15 \%$ of those who do not work in the shadow economy. Those who think it is almost certain that they will be caught by the tax authorities when working in the shadow economy are $9.6 \%$, compared to $22.3 \%$ of those who are not working in the shadow economy. $37.7 \%$ of those, who work in the shadow economy, think, that the income taxes are too high, compared to $19.4 \%$ who are not working in the shadow economy. These results point out some similarities to the results found in this paper, so that a general conclusion may be that those who evade taxes believe to a higher extend that taxes and that the tax burden is too high, the risk of being caught is less likely, compared to those, who do not evade taxes (do not work in the shadow economy).
} 
expected under hypothesis 2. Thus, our results indicate that participants not only discriminated in their spontaneously produced associations between tax avoidance, tax evasion, and tax flight, but that they also perceived them as unequally fair and evaluated them differently. As expected, tax avoidance was perceived rather positively, tax flight rather neutrally, and tax evasion rather negatively.

With regard to the neutrality index, the analysis of variance revealed a main effect for employment group $(\mathrm{F}(3 ; 208)=5.60 ; \mathrm{p}<.01)$, whereas the scenario had no influence $(\mathrm{F}(2$; $208)=1.23, \mathrm{p}=.29)$ on the evaluation of spontaneously produced associations. Fiscal officers $(\mathrm{M}=.35 ; \mathrm{SD}=.29)$ and entrepreneurs $(\mathrm{M}=.31 ; \mathrm{SD}=.32)$ produced the least neutral associations, followed by business lawyers $(\mathrm{M}=.24 ; \mathrm{SD}=.27)$. And finally, business students produced rather neutral associations $(\mathrm{M}=.17$; $\mathrm{SD}=.23)$. These results can be interpreted in terms of personal affectedness and experience. The only group with no or little experience with taxes is the group of business students. The group of business lawyers are mainly indirectly affected by taxes due to their task of advising clients in tax matters. Thus, not surprisingly these employment groups produced rather neutral associations to the tax scenarios. To the contrary, entrepreneurs and fiscal officers are more directly affected by tax matters: Entrepreneurs have to pay them out of their pockets, and fiscal officers have to collect them. Correspondingly, both employment groups are not only affected by taxes, but are also emotionally involved. Therefore, it is not surprising that both employment groups, entrepreneurs and fiscal officers, produced the least neutral associations.

\subsection{Subjective fairness of tax behavior}

Participants in all experimental conditions were asked to answer three items on subjective fairness of tax avoidance, tax evasion, and tax flight on a nine-step scale, ranging from $1=$ unfair to 9 = fair. We hypothesized that despite the fact that tax avoidance, tax evasion, and tax flight lead to identical economic consequences, they are not perceived as equally fair by taxpayers. It was expected that tax avoidance is evaluated fairer than tax flight which in turn is evaluated fairer than tax evasion.

A repeated analysis of variance with tax avoidance, tax evasion, and tax flight as repeated factor and employment group as independent factor indicates significant differences between the sample $(\mathrm{F}(3 ; 243)=9.18, \mathrm{p}<.001)$. Fiscal officers found all forms of tax reduction less fair than business students, business lawyers, and entrepreneurs. These results may reflect the high moral standards of fiscal officers, leading them to generally evaluate all forms of tax reduction more negatively than others.

In all employment groups tax avoidance was considered to be fairest $(\mathrm{M}=8.17$; $\mathrm{SD}=1.84)$, whereas tax evasion was considered to be least fair $(\mathrm{M}=2.92$; $\mathrm{SD}=2.27)$. Subjective fairness of tax flight was rated in between tax avoidance and tax evasion $(\mathrm{M}=6.34$; $\mathrm{SD}=2.79)$, as expected under hypothesis 2 . Figure 3 indicates that fiscal officers generally perceived all three tax-reduction possibilities to be less fair, whereas entrepreneurs considered tax flight to be fairer in comparison to others, outlining that entrepreneurs are the only employment group in our analysis that can consider tax flight as a way to reduce their tax burden. 
Figure 3: Perceived fairness of tax avoidance, tax evasion, and tax flight with respect to employment group



Fiscal officers

Business students

Business lawyers

Entrepreneurs

\subsection{Attitudes and perceived fairness within the context of tax knowledge}

Overall, participants were asked to answer 10 multiple-choice questions on tax knowledge (see Appendix B; Cronbach $\alpha=.62$ ). In each question they had to choose the correct answer out of four possible ones. An index was computed out of the ten questions, ranging from $0=$ no correct answers to $1=$ all questions correctly answered.

An analysis of variance with tax knowledge as dependent factor and employment group as independent factor yields significant differences between the sample with respect to knowledge $(\mathrm{F}(3 ; 238)=74.88, \mathrm{p}<.001)$. Fiscal officers scored highest $\left(\mathrm{M}_{\mathrm{F}}=.94, \mathrm{SD}_{\mathrm{F}}=.08\right)$, followed by business students $\left(\mathrm{M}_{\mathrm{S}}=.88, \mathrm{SD}_{\mathrm{S}}=.12\right)$, and business lawyers $\left(\mathrm{M}_{\mathrm{L}}=.80, \mathrm{SD}_{\mathrm{L}}=\right.$ $.20)$. Entrepreneurs, on the contrary, achieved the poorest results $\left(\mathrm{M}_{\mathrm{E}}=.51, \mathrm{SD}_{\mathrm{E}}=.18\right)$, may be because they rely on professional advice when tax issues are concerned.

With respect to hypothesis 3, it was investigated whether tax knowledge is positively correlated with attitudes towards tax avoidance and negatively correlated with attitudes towards tax evasion. Our results, however, do not confirm this conjecture. Considering the whole sample, tax knowledge is neither correlated with the perceived fairness of tax evasion $(\mathrm{r}(238)=-.06, \mathrm{p}=.33)$, nor with the perceived fairness of tax avoidance $(\mathrm{r}(242)=-.02, \mathrm{p}=$ $.80)$. However, for the sub-sample of business lawyers and entrepreneurs it was shown that profound tax knowledge is positively correlated with perceived fairness of tax avoidance $(\mathrm{r}(56)=.56, \mathrm{p}<.001 ; \mathrm{r}(37)=.33, \mathrm{p}<.05)$, indicating that the better the knowledge the fairer 
was tax avoidance perceived. For the sub-sample of fiscal officers, on the other hand, it could be shown that tax knowledge is negatively correlated with perceived fairness of tax evasion $(r(70)=-.24, p<.05)$, indicating that the lower the knowledge about taxes the fairer illegal evasion was judged.

\subsection{Individual tax compliance within the context of employment group}

Participants assigned to the experimental condition "tax evasion" were asked to state how much they think the person described in the scenario would honestly declare to the tax authorities. In line with previous empirical evidence, we hypothesized that opportunity influences individual tax compliance. More precisely, it was expected that individual tax compliance would be lower for the group of business entrepreneurs than for the employed groups of business lawyers and fiscal officers. Since business students do not have a regular income from work, they are not considered in the subsequent analysis.

An analysis of variance with individual tax compliance as dependent factor and employment group as independent factor yields no significant differences between the sample $(\mathrm{F}(1 ; 42)=$ $0.02, \mathrm{p}=.96)$. The relative frequency of declared income was not statistically significantly lower for the group of business entrepreneurs $(\mathrm{M}=.24, \mathrm{SD}=.27)$ compared to the group of business lawyers and fiscal officers $(\mathrm{M}=.24, \mathrm{SD}=.39)$. Thus, our results do not confirm the role of opportunity with respect to individual tax compliance, we therefore cannot reject the null-hypothesis, indicating that individual tax compliance is the same for business entrepreneurs as well as for business lawyers and fiscal officers. However, in line with previous empirical studies showing that income is negatively correlated with individual tax compliance (e.g., Anderhub, Giese, Güth, Hoffmann and Otto, 1999; Maciejovsky, Kirchler and Schwarzenberger, 2001), we found - at least for the group of business entrepreneurs - that a higher income is connected to a low tax compliance $(\mathrm{r}(31)=-.39, \mathrm{p}<.05)$.

\section{Conclusion}

The results show that despite the similar effects of tax avoidance, tax evasion, and tax flight on revenue yields, 252 fiscal officers, business students, business lawyers, and entrepreneurs clearly discriminated in their spontaneously produced associations between them. Tax avoidance was perceived as legal and as moral, and was amongst others associated with intention to save taxes, with cleverness and with a good idea. Tax evasion, on the other hand, was perceived as illegal and immoral, and was, for instance, associated with fraud, criminal prosecution, risk, tax-audit, and with penalty. Finally, tax flight was perceived as legal and as immoral, and was amongst others associated with intention to save taxes, with an impression that taxes are lower abroad and with costs of relocating.

The results also indicate that taxpayers not only discriminate between tax avoidance, tax evasion, and tax flight, but also perceive them as unequally fair. Tax avoidance was more positively evaluated than tax flight and than tax evasion, which was least positively evaluated. These results were found to hold irrespective of employment group. However, fiscal officers perceived all three forms of tax reduction to be less fair, whereas entrepreneurs considered tax flight to be fairer in comparison to others. In addition, the results indicate that for business lawyers and for entrepreneurs profound tax knowledge is positively correlated with perceived fairness of tax avoidance, indicating that the better one's knowledge about tax law the fairer one perceives legal tax avoidance. To the contrary, the results show that for fiscal officers tax knowledge was found to be negatively correlated with perceived fairness of tax evasion, 
indicating that the lower the knowledge about taxes the fairer illegal evasion was perceived. Furthermore, our results could not confirm the role of opportunity in individual tax compliance, indicating that business entrepreneurs were not less compliant than business lawyers and fiscal officers. However, in line with previous empirical studies it was found that income is negatively correlated with tax compliance.

In conclusion, our results indicate that lay concepts about taxes, more precisely about tax avoidance, tax evasion, and tax flight, seem to be determined not only by economic aspects but also by moral considerations (Etzioni, 1988). It could be shown that despite the fact that tax avoidance, tax evasion, and tax flight lead to similar effects on revenue yields, taxpayers discriminate between them and evaluate them differently. Moreover, it could be shown that these evaluations depend, for instance, on personal affectedness, experience, profession, and knowledge. 


\section{References}

Abric, J. C. 1996. Specific processes of social representations. Papers on Social Representations - Textes sur les Représentations Sociales, 5, 77-80.

Allingham, M. G. and Sandmo, A. 1972. Income tax evasion: A theoretical analysis. Journal of Public Economics, 1, 323-338.

Alm, J., McClelland, G. H. and Schulze, W. D. 1992. Why do people pay taxes? Journal of Public Economics, 48, 21-38.

Alm, J., McClelland, G. H. and Schulze, W. D. 1999. Changing the social norm of tax compliance by voting. Kyklos, 52, 141-171.

Anderhub, V., Giese, S., Güth, W., Hoffmann, A. and Otto, T. 1999. Tax evasion with earned income and varying tax rate: An experimental study. Discussion Paper 142. HumboldtUniversity of Berlin, Germany.

Baldry, J. C. 1987. Income tax evasion and the tax schedule: Some experimental results. Public Finance, 42, 357-383.

Bosco, L. and Mittone, L. 1997. Tax evasion and moral constraints: Some experimental evidence. Kyklos, 50, 297-324.

Chang, O. H., Nichols, D. R. and Schultz, J. J. 1987. Taxpayer attitudes towards tax audit risk. Journal of Economic Psychology, 8, 299-309.

Clotfelter, C. T. 1983. Tax evasion and tax rates: An analysis of individual returns. The Review of Economics and Statistics, 65, 363-373.

Cross, R. B. and Shaw, G. K. 1982. The evasion-avoidance choice: A suggested approach. National Tax Journal, 34, 489-491.

Cullis, J. G. and Lewis, A. 1997. Why people pay taxes: From a conventional economic model to a model of social convention. Journal of Economic Psychology, 18, 305-321.

De Rosa, A. S. 1996. Controversial social representations "of" and "around" advertising: How to sell pullovers by provoking discussion on social issue. Symposium organized by the 11th General Meeting of EAESP, July, 1996, Gmunden, Austria.

Dornstein, M. 1987. Taxes: Attitudes and perceptions and their social bases. Journal of Economic Psychology, 8, 55-76.

Eriksen, K. and Fallan, L. 1996. Tax knowledge and attitudes towards taxation: A report on a quasi-experiment. Journal of Economic Psychology, 17, 387-402.

Etzioni, A. 1988. The Moral Dimension. Toward a New Economy. New York: Free Press.

Groenland, E. A. G. and van Veldhoven, G. M. 1983. Tax evasion behavior: A psychological framework. Journal of Economic Psychology, 3, 129-144.

Kaplan, S. E. and Reckers, P. M. J. 1985. A study of tax evasion judgments. National Tax Journal, 38, 97-102.

Kinsey, K. A. 1984. Survey data on tax compliance: A compendium and review. Working Paper 84-1. Chicago: American Bar Foundation.

Kirchler, E. 1997. Balance between giving and receiving: Tax morality and satisfaction with fiscal policy as they relate to the perceived just distribution of public resources. Reitaku International Journal of Economic Studies, 5, 59-70. 
Kirchler, E. 1999. Reactance to taxation: Employers' attitudes towards taxes. Journal of Socio-Economics, 28, 131-138.

Kirchler, E. and Maciejovsky, B. (2001). Tax compliance within the context of gain and loss situations, expected and current asset position, and profession. Journal of Economic Psychology, 22, 173-194.

Lewis, A. 1979. An empirical assessment of tax mentality. Public Finance, 34, 245-257.

Maciejovsky, B., Kirchler, E. and Schwarzenberger, H. 2001. Mental accounting and the impact of tax penalty and audit frequency on the declaration of income: An experimental analysis. Discussion Paper 16, SFB-373, Humboldt University of Berlin, Germany.

Moscovici, S. 1981. On social representations. In: J. Forgas (ed.). Social Cognition. Perspectives on Everyday Understanding. London: Academic Press.

Moscovici, S. 1984. The phenomenon of social representations. In: R. Farr and S. Moscovici (eds.). Social Representations: European Studies in Social Psychology. Cambridge: Cambridge University Press.

Moscovici, S. and Hewstone, M. 1983. Social representations and social explanations: From the "naive" to the "amateur" scientist. In: M. Hewstone (ed.). Attribution Theory: Social and Functional Extension. Oxford: Blackwell.

Porcano, T. M. 1988. Correlates of tax evasion. Journal of Economic Psychology, 9, 47-67.

Robben, H. S. J., Webley, P., Elffers, H. and Hessing, D. J. 1990. Decision frames, opportunity and tax evasion: An experimental approach. Journal of Economic Behavior and Organization, 14, 353-361.

Schepanski, A. and Shearer, T. 1995. A prospect theory account of the income tax withholding phenomenon. Organizational Behavior and Human Decision Processes, 63, 174-186.

Schneider, F., Braithwaite, V. and Reinhart, M. 2001. Individual behaviour in the shadow economy in Australia: Facts, empirical findings and some mysteries. Discussion Paper. University of Linz, Deparment of Economics.

Slemrod, J. and Yitzhaki, S. 2000. Tax avoidance, evasion, and administration. National Bureau of Economic Research, Working Paper 7473.

Song, Y. and Yarbrough, T. E. 1978. Tax ethics and taxpayer attitudes: A survey. Public Administration Review, 38, 442-457.

Spicer, M. W. and Becker, L. A. 1980. Fiscal inequity and tax evasion: An experimental approach. National Tax Journal, 33, 171-175.

Spicer, M. W. and Lundstedt, S. B. 1976. Understanding tax evasion. Public Finance, 31, 295-305.

Vergès, P. 1987. A social and cognitive approach to economic representations. In: W. Doise and S. Moscovici (eds.). Current Issues in European Social Psychology. Cambridge: Cambridge University Press.

Vergès, P. 1996. A method of analysis by questionnaires to know social representations of the economy, Paper presented at the 21th Annual Meeting of IAREP, July, 1996, Paris, France. 
Vergès, P. and Bastounis, M. 2001. Towards the investigation of social representations of the economy : Research methods and techniques. In: C. Roland-Lévy, E. Kirchler, E. Penz and C. Gray (eds.). Everyday Representations of the Economy. Vienna: WUV.

Vogel, J. 1974. Taxation and public opinion in Sweden: An interpretation of recent survey data. National Tax Journal, 37, 499-514.

Wärneryd, K.-E. and Walerud, B. 1982. Taxes and economic behavior: Some interview data on tax cheating in Sweden. Journal of Economic Psychology, 2, 187-211.

Wallschutzky, I. G. 1984. Possible causes of tax evasion. Journal of Economic Psychology, 5, 371-384.

Webley, P., Robben, H., Elffers, H. and Hessing, D. 1991. Tax Evasion: An Experimental Approach. Cambridge: Cambridge University Press.

Weigel, R. H., Hessing, D. J. and Elffers, H. 1987. Tax evasion research: A critical appraisal and theoretical model. Journal of Economic Psychology, 8, 215-235. 
Table 4: Frequencies of categorized associations by employment group and scenario

\begin{tabular}{|c|c|c|c|c|c|c|c|c|c|c|c|c|c|}
\hline \multirow{3}{*}{ No. } & \multirow{3}{*}{ Category } & \multicolumn{3}{|c|}{ Fiscal officers } & \multicolumn{3}{|c|}{ Business students } & \multicolumn{3}{|c|}{ Business lawyers } & \multicolumn{3}{|c|}{ Entrepreneurs } \\
\hline & & & Tax & & & Tax & & & Tax & & & Tax & \\
\hline & & Avoidance & Evasion & Flight & Avoidance & Evasion & Flight & Avoidance & Evasion & Flight & Avoidance & Evasion & Fligh \\
\hline 1 & Intentional tax evasion & 3 & 11 & 2 & 3 & 12 & 0 & 1 & 4 & 0 & 0 & 5 & 0 \\
\hline 2 & Tax evasion based on errors & 0 & 1 & 0 & 0 & 0 & 1 & 0 & 1 & 0 & 0 & 1 & 0 \\
\hline 3 & Intransparency of the tax system & 0 & 0 & 0 & 2 & 0 & 0 & 0 & 1 & 0 & 0 & 0 & 1 \\
\hline 4 & Tax havens & 1 & 0 & 6 & 2 & 0 & 3 & 0 & 0 & 1 & 0 & 0 & 4 \\
\hline 5 & Legal tax reduction & 5 & 0 & 2 & 6 & 5 & 8 & 6 & 0 & 3 & 2 & 0 & 0 \\
\hline 6 & Economic advantages of tax flight & 0 & 0 & 1 & 0 & 0 & 1 & 0 & 0 & 3 & 0 & 0 & 1 \\
\hline 7 & Flight abroad & 2 & 2 & 13 & 1 & 0 & 11 & 1 & 0 & 13 & 0 & 0 & 1 \\
\hline 8 & Injustice & 2 & 1 & 1 & 0 & 0 & 0 & 0 & 1 & 0 & 1 & 3 & 0 \\
\hline 9 & Vertical justice & 0 & 1 & 0 & 0 & 0 & 0 & 0 & 0 & 1 & 0 & 1 & 0 \\
\hline 10 & Horizontal justice & 2 & 2 & 0 & 0 & 0 & 0 & 0 & 0 & 0 & 0 & 1 & 0 \\
\hline 11 & Cleverness & 2 & 0 & 0 & 3 & 2 & 1 & 5 & 1 & 0 & 0 & 2 & 0 \\
\hline 12 & Audit and sanction & 0 & 8 & 1 & 0 & 12 & 0 & 0 & 3 & 2 & 0 & 5 & 0 \\
\hline 13 & Individual justification & 1 & 1 & 0 & 2 & 0 & 0 & 0 & 2 & 1 & 0 & 1 & 0 \\
\hline 14 & Personal advantage & 1 & 2 & 1 & 4 & 1 & 3 & 5 & 5 & 4 & 2 & 2 & 6 \\
\hline 15 & Illegal & 1 & 7 & 0 & 0 & 10 & 0 & 2 & 5 & 0 & 1 & 2 & 0 \\
\hline 16 & Peccadillo & 0 & 2 & 1 & 0 & 0 & 1 & 0 & 4 & 0 & 1 & 2 & 0 \\
\hline 17 & Negative consequences of tax flight & 0 & 0 & 1 & 0 & 0 & 1 & 1 & 0 & 1 & 0 & 1 & 3 \\
\hline 18 & Economic consequences & 1 & 1 & 0 & 0 & 2 & 2 & 0 & 0 & 3 & 0 & 0 & 1 \\
\hline 19 & Tax types & 0 & 2 & 2 & 1 & 0 & 0 & 3 & 2 & 1 & 0 & 0 & 0 \\
\hline 20 & Harmonization of the tax system & 3 & 0 & 1 & 0 & 0 & 0 & 0 & 0 & 2 & 0 & 0 & 0 \\
\hline 21 & Bureaucracy & 0 & 0 & 2 & 0 & 1 & 4 & 0 & 0 & 1 & 0 & 0 & 1 \\
\hline 22 & Criticism on the tax system & 0 & 0 & 1 & 3 & 1 & 4 & 0 & 2 & 1 & 0 & 0 & 1 \\
\hline 23 & Unprofitable & 0 & 1 & 2 & 1 & 2 & 2 & 0 & 0 & 3 & 0 & 1 & 2 \\
\hline 24 & Unacceptance of tax reduction & 0 & 0 & 1 & 0 & 2 & 0 & 1 & 9 & 3 & 0 & 4 & 1 \\
\hline 25 & Opportunity & 0 & 0 & 0 & 0 & 2 & 0 & 0 & 2 & 0 & 0 & 0 & 0 \\
\hline 26 & Make use of tax allowances & 6 & 1 & 1 & 3 & 1 & 1 & 4 & 1 & 0 & 0 & 0 & 0 \\
\hline 27 & Wish to reduce the tax burden & 1 & 0 & 5 & 0 & 3 & 3 & 1 & 1 & 4 & 0 & 0 & 1 \\
\hline 28 & Risk tendency & 1 & 3 & 2 & 1 & 12 & 0 & 3 & 4 & 1 & 0 & 6 & 1 \\
\hline 29 & Tax loophole & 8 & 0 & 0 & 5 & 0 & 1 & 5 & 1 & 0 & 5 & 0 & 0 \\
\hline 30 & Acceptance of tax reduction & 4 & 1 & 4 & 8 & 3 & 2 & 8 & 0 & 1 & 6 & 3 & 1 \\
\hline 31 & Black money & 0 & 1 & 0 & 0 & 8 & 0 & 1 & 3 & 0 & 0 & 2 & 0 \\
\hline 32 & Reactance & 1 & 0 & 0 & 0 & 0 & 0 & 0 & 0 & 0 & 0 & 1 & 0 \\
\hline 33 & Tax law & 2 & 2 & 5 & 4 & 2 & 6 & 1 & 0 & 4 & 0 & 0 & 0 \\
\hline 34 & Tax office & 0 & 6 & 4 & 4 & 6 & 2 & 0 & 1 & 1 & 0 & 0 & 1 \\
\hline
\end{tabular}


Figure 2: Correspondence analysis of associations on tax avoidance, tax evasion, and tax flight with respect to employment group

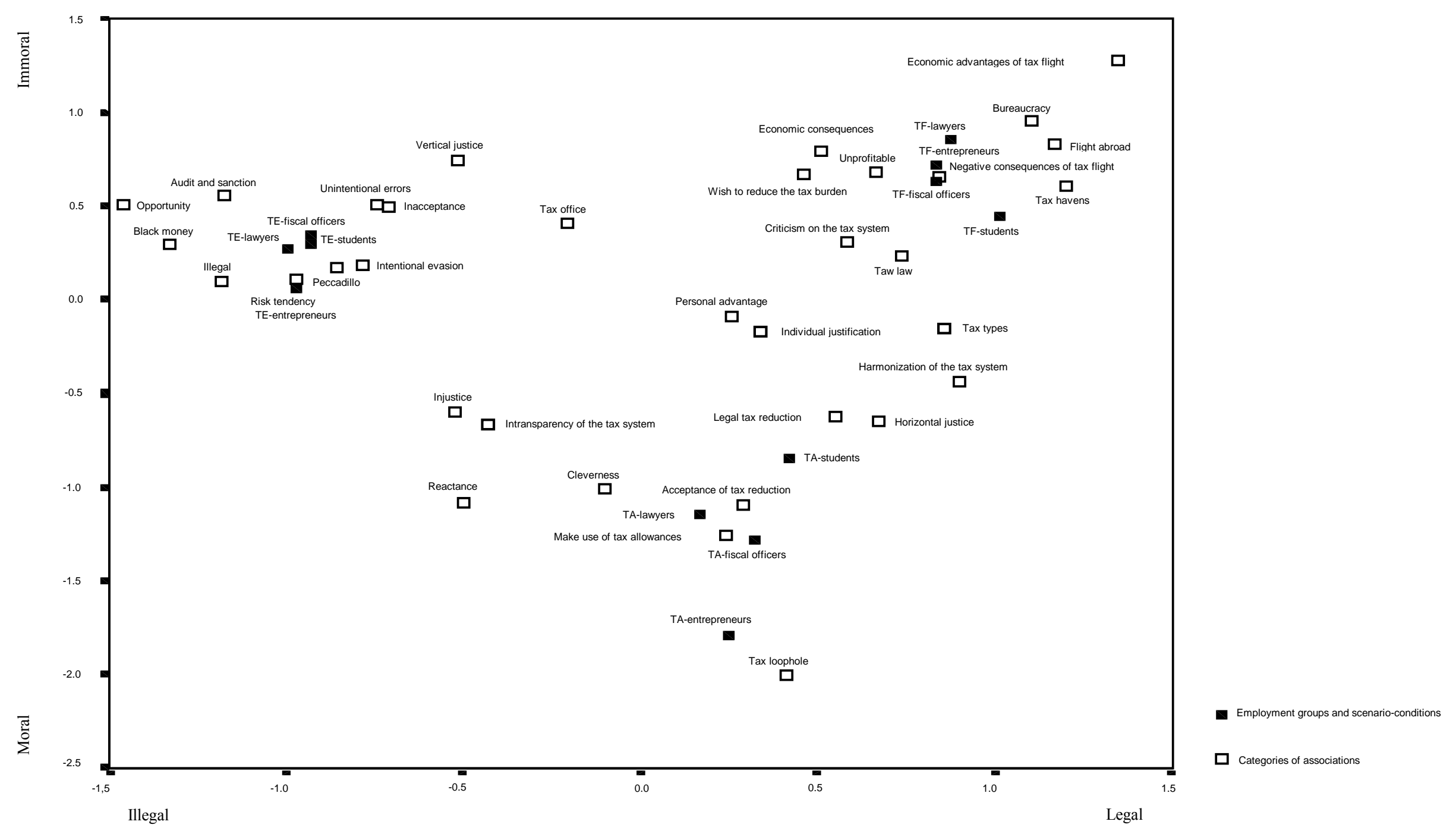




\section{Appendix B:}

Multiple-choice test on tax knowledge (correct answers are indicated in italics).

1. Austria's top marginal income tax-rate is? $(32 \% ; 42 \% ; 50 \% ; 60 \%)$

2. For which of the following expenditures there is no tax allowance? (third party insurance; insurance premium for retirement; payments for tax consultants; payments for officially registered religious bodies)

3. Which tax had to be harmonized after Austria joined the European Union? (local taxes; value-added tax; income tax; capital yields tax)

4. How does the sales tax differ from value-added tax in Austria? (the sales tax is $10 \%$, whereas the value-added tax is $20 \%$; the sales tax is $20 \%$, whereas the value-added tax is $10 \%$; both taxes are synonyms; sales tax refers to entrepreneurs, whereas value-added tax refers to consumers)

5. The corporate income tax in Austria is? $(25 \% ; 34 \% ; 48 \% ; 60 \%)$

6. Which of the following positions is not an essential part of a receipt? (time; date; amount; value-added tax)

7. What exception allows a financial year to be shorter than twelve months? (a company is being set up or shut down; tax authorities gain more insight in companies' affairs; a shorter financial year is not allowed; a shorter financial year can be chosen individually)

8. Which of the following legal forms belongs to legal entities? (ordinary partnerships; sole proprietors; corporations; limited partnerships)

9. When is income tax not applicable? (when the income is illegal; when the income is not listed in the codified law; when the income has already been subject to another tax; there is no reason that income tax is not applicable)

10. Financial asset gains that belong to companies' fixed assets of a limited are part of which income source? (business income; self-employed income; income from capital gains; other income) 